\title{
GPR Tomography as Support for an Archaeological Excavation in Aripuanã Indigenous Cemetery, Amazon Region, Brazil
}

\author{
Jorge Luís Porsani ${ }^{1}$, Renato Kipnis ${ }^{2}$, Vinícius Rafael Neris dos Santos ${ }^{1}$, \\ Emerson Rodrigo Almeida', Iris Fernandes ${ }^{1}$
}

\author{
${ }^{1}$ Universidade de São Paulo, Instituto de Astronomia, Geofísica e Ciências Atmosféricas, Departamento de Geofísica, \\ São Paulo, Brazil \\ ${ }^{2}$ Scientia Consultoria Científica, São Paulo, Brazil \\ Email: jorge.porsani@iag.usp.br, vinicius@iag.usp.br, em erson@iag.usp.br, \\ rkipnis@scientiaconsultoria.com.br
}

How to cite this paper: Porsani, J.L., Kipnis, R., dos Santos, V.R.N., Almeida, E.R. and Fernandes, I. (2017) GPR Tomography as Support for an Archaeological Excavation in Aripuanã Indigenous Cemetery, Amazon Region, Brazil. International Journal of Geosciences, 8, 1264-1277. https://doi.org/10.4236/ijg.2017.810073

Received: August 28, 2017

Accepted: October 28, 2017

Published: October 31, 2017

Copyright ( 92017 by authors and Scientific Research Publishing Inc. This work is licensed under the Creative Commons Attribution International License (CC BY 4.0).

http://creativecommons.org/licenses/by/4.0/

(c) (i) Open Access

\begin{abstract}
We present here a series of Ground Penetrating Radar (GPR) survey carried out in different areas of the Dardanelos 1 archaeological site in order to generate information about subsurface anomalies associated with archaeological material that could be use in decision making within the environmental licensing process of the Dardanelos Hydroelectric Power Plant, located near of the Aripuanã city, Mato Grosso State, northwest region of Brazil. GPR surveys with $200 \mathrm{MHz}$ antenna were carried out in two blocks aiming to locate archaeological resources and features. The analysis of GPR 2D and 3D results allowed detecting anomalous regions characterized by hyperbolic reflections, shallow elongated continuous targets with high amplitudes, as well as sub-horizontal reflectors. Microwave tomography allowed estimating the geometry of the GPR anomalies sources. Excavations were done by archaeologists at the locations where hyperbolic anomalies were found, revealing interesting structures related to urns in the middle of a rich in organic matter consisting of black and ceramic materials up to about $1 \mathrm{~m}$ deep. The first sub-horizontal reflector at approximately $1 \mathrm{~m}$ depth is related to the base of the black soil layer rich in organic matter and the second sub-horizontal reflector between 2 and $3 \mathrm{~m}$ deep suggests a lithological change or may be related to presence of the water table. The continuous elongated shallow targets observed in the depth slices are related to tree roots in the middle of the archaeological strata. The GPR results guided archaeological excavations, reduced the time and costs involved in research, and contributed to the preservation of Brazilian historical heritage.
\end{abstract}




\section{Keywords}

Ground Penetrating Radar (GPR), Microwave Tomography, Archaeology, Anthropogenic Soil, Dardanelos Hydroelectric Power Plant, Amazon Region, Brazil

\section{Introduction}

The use of geophysical methods in archaeological investigations has increased considerably in recent decades. In particular, the Ground Penetrating Radar (GPR) method [1] [2] has contributed to non-destructive actions, guiding archaeological excavations, reducing costs and time related to research and excavations. GPR permits to obtain lateral and vertical information in high resolution about the shallow subsurface. The results can be presented by $2 \mathrm{D}$ profiles and $3 \mathrm{D}$ profiles as fence diagrams, interpolated cubes and amplitude maps in depth slices [3] [4]. Some interesting results of GPR investigations in archaeological studies can be found in the literature [5]-[11], among others.

In Brazil, the researcher Anna Roosevelt used the GPR for the first time on the Marajó Island to map archeological sites made of ceramic materials [12], followed by [13]. Ten years later, Cezar et al. [14] also employed GPR to search for ceramic materials from archaeological sites in Rio de Janeiro State. Other geophysical researches in archaeological investigations include fluvial sambaquis [15], coastal sambaquis [16], shelter on rock [17], archaeology in urban areas [18].

In this paper, GPR surveys were carried out in the framework of the environmental licensing of the Dardanelos Hydroelectric Power Plant, Mato Grosso State, northwestern of Brazil (Figure 1). Dardanelos is located in the municipality of Aripuanã, where the Aripuanã river passes, located in the region of the legal Amazon. The hydroelectric is located on the left bank of the middle Aripuanã river, opposite of Aripuanã city. The region has been a logging and agricultural expansion front since the 1970s, and was also the nucleus of the project known as the Humboldt Science City (Aripuanã Project). The Cinta Larga and Arara indigenous people have inhabited the region since immemorial times, and are nowadays the traditional inhabitants of the region that covers the Municipality of Aripuanã and, in turn, the basin of the homonymous river and the Salto de Dardanelos [19].

The archaeological research was carried out in the area of the Dardanelos Hydroelectric Power Plant, a large prehistoric village known as Daradanelos 1 archeological site. This village is formed by sedentary populations, agricultural practitioners and producers of numerous ceramic vessels, lithic artifacts, and anthropogenic black earth formation.

In this framework, the present study shows the microwave tomography (MT) results of 2D and 3D GPR surveys with $200 \mathrm{MHz}$ antenna in two blocks of 

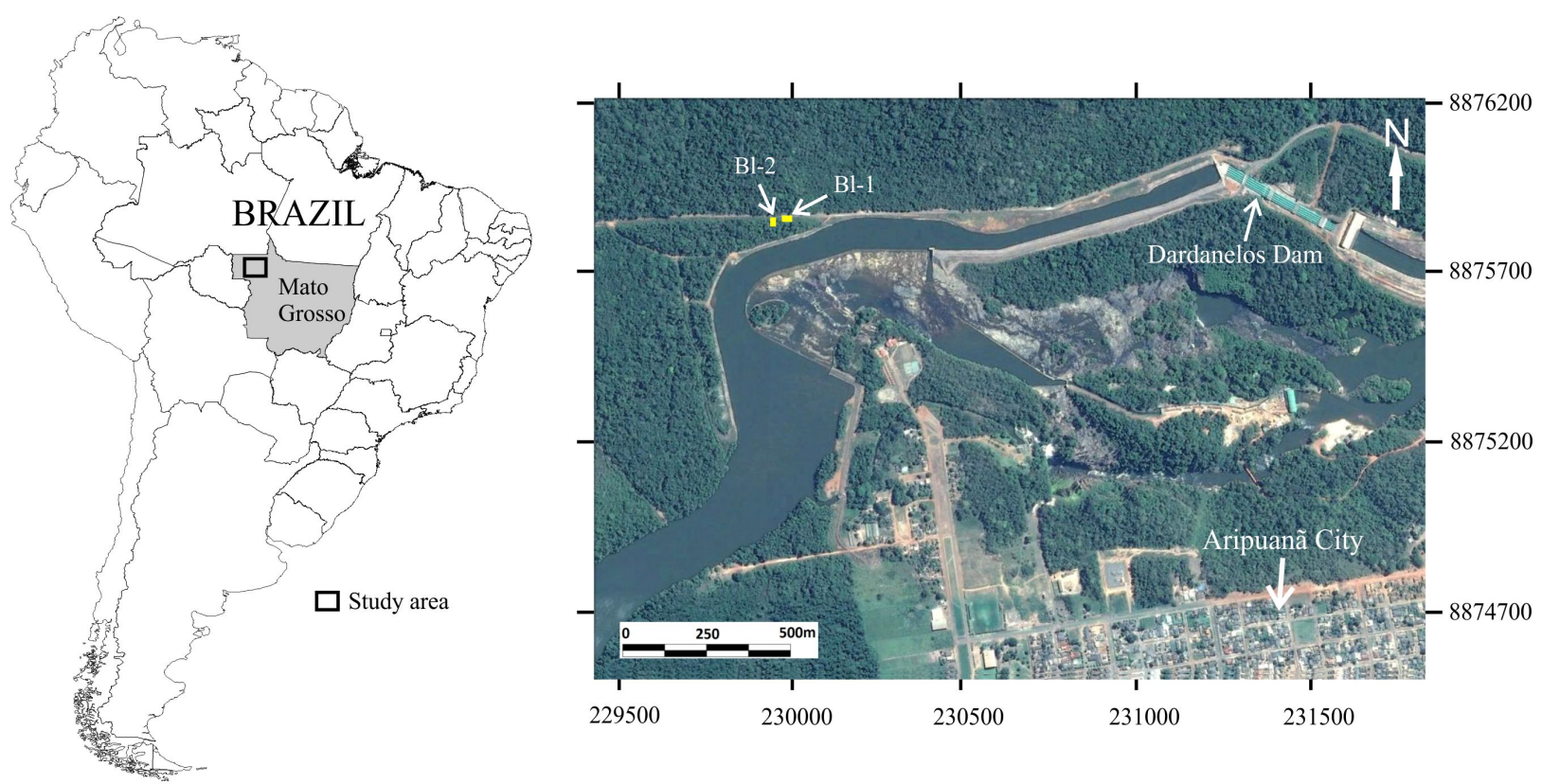

Figure 1. Location map of the study area near the Dardanelos hydroelectric power plant, State of Mato Grosso-MT, northwest region of Brazil (Adapted image from Google Earth [35]).

studies inside the archaeological site of Dardanelos 1. The advantage of MT is that it permits to recover the geometry of the anomalies in subsurface that cause hyperbolic reflections. The main goal was to identify areas of greater archaeological sensitivity as an alternative to avoid the impact in areas of greater sensitivity, guiding archaeological excavations, reducing costs and excavation time, and assisting in protection measures. Interesting results of this research are presented in this paper, which revealed large urns, some of which might contain human remains, contributed to the preservation of the national patrimony and showed the importance of using the GPR method in archaeological studies.

\section{Area of Study and Archaeological Context}

The study area is located on the left bank of the Aripuanã river, municipality of Aripuanã, northwest region of the Mato Grosso State, Brazil. It is located around $700 \mathrm{~km}$ from Cuiabá city in the Mato Grosso State and about $510 \mathrm{~km}$ from the Porto Velho city in the Rondônia State. The municipality of Aripuanã is located in the region comprised by the legal Amazon. The geophysical survey was carried out in two blocks of studies at the archaeological site of Dardanelos 1 (Figure 1).

The area of the Dardanelos is located in a region characterized by great environmental diversity, as a result of its location in a transition area between the Chapada de Dardanelos and the Amazonian Depression, the latter consisting of a more reduced topography area. The Aripuanã river basin itself is in a transition region between the Amazonian and cerrado forest domains that occur in the Central Plateau. 
In the contact between the Chapada de Dardanelos and the Depression, there are two great waterfalls, the Salto de Dardanelos and the Salto das Andorinhas. To the south of these waterfalls, on the right bank, is the urban area of Aripuanã, and on the left bank the archaeological site Dardanelos 1 (Figure 1).

The Aripuanã river basin is a promising archaeological area, in the interplay of the Madeira-Tapajós rivers, considered as one of the routes of expansion of the Tupi and Proto-Tupi groups in pre-colonial times. The region is characterized as an extensive open-air ceramic site that covers a 1300 meter extension with the presence of anthropic black soil, housing the Dardanelos 1 site that features ceramics of diverse affiliation, such as Borda Incisa, Tupi and others.

Sixteen radiocarbon dates were obtained from charred samples sent to Beta Analytic (Table 1). A very ancient assay of $7700 \pm 50$ BP (ARIP05) and a more recent one dated to $150 \pm 40 \mathrm{BP}$ (ARIP02) are stratigraphic inversion and it is yet not clear if they are associated with archaeological levels. The other thirteen assays present stratigraphic coherence, are associated with archaeological levels presenting rich material culture, strongly suggesting occupation of the site between $1490 \pm 40$ and $4890 \pm 40$ years before present by indigenous societies that were manufacturing ceramic and lithic artifacts, and based on producing economy associated with Amazonian Dark Earth.

Table 1. Radiocarbon assays obtained from Dardanelos 1 charred samples grouped by spatial proximity.

\begin{tabular}{|c|c|c|c|c|c|}
\hline Sample \# & Lab \# & UTM N & UTM E & Level $(\mathrm{cm})$ & Date BP \\
\hline ARIP03 & 244,674 & $8,875,780$ & 230,640 & $40-50$ & $1960 \pm 40$ \\
\hline ARIP04 & 244,675 & $8,875,780$ & 230,640 & $70-80$ & $4160 \pm 40$ \\
\hline ARIP01 & 244,672 & $8,875,800$ & 229,900 & $40-50$ & $1650 \pm 40$ \\
\hline ARIP08 & 244,679 & $8,875,800$ & 229,900 & $110-120$ & $4370 \pm 60$ \\
\hline ARIP06 & 244,677 & $8,875,820$ & 229,940 & $80-90$ & $2090 \pm 50$ \\
\hline ARIP05 & 244,676 & $8,875,819$ & 229,921 & $80-90$ & $7700 \pm 50$ \\
\hline ARIP09 & 244,680 & 8875780 & 229,900 & $110-120$ & $2370 \pm 50$ \\
\hline ARIP14 & 278,354 & $8,875,910$ & 229,925 & $40-50$ & $1490 \pm 40$ \\
\hline ARIP13 & 278,353 & $8,875,910$ & 229,925 & $90-100$ & $1620 \pm 40$ \\
\hline ARIP11 & 278,351 & $8,875,910$ & 229,925 & $140-150$ & $1910 \pm 40$ \\
\hline ARIP02 & 244,673 & $8,876,240$ & 230,640 & $40-50$ & $150 \pm 40$ \\
\hline ARIP07 & 244,678 & $8,876,200$ & 230,620 & $90-100$ & $2520 \pm 40$ \\
\hline ARIP17 & 278,357 & $8,876,180$ & 230,560 & $100-120$ & $3080 \pm 50$ \\
\hline ARIP15 & 278,355 & $8,875,860$ & 229,600 & $\begin{array}{c}\text { Fire hearth } \\
\text { N7 }\end{array}$ & $1890 \pm 40$ \\
\hline ARIP16 & 278,356 & $8,875,939$ & 230,519 & Feature 1 & $1920 \pm 40$ \\
\hline ARIP12 & 278,352 & $8,876,258$ & 229,680 & $60-70$ & $4890 \pm 40$ \\
\hline
\end{tabular}


The upper Madeira River region, although not well-known archaeologically, shows signs of ancient occupations, dating to the beginning of the Holocene, around 9000 years before the present (BP) and includes what appear to be the oldest anthropogenic soil throughout the Amazon [20]. This region is still the supposed center of initial domestication of economically important plants in the Amazon, such as manioc (Manihot esculenta) and pupunha (Bactris gasipaes). Finally, this may also be the initial center of dispersion of Tupi-speaking peoples [21].

The oldest pre-colonial occupations in the Mato Grosso and Rondônia States are related to the occupation of the region by hunter-gatherer societies with great mobility, especially recognized by the remnants of the production and use of lithic artifacts produced by flaking technique (Itaparica Tradition, Serranópolis Tradition and Dourado Complex). They dominated the region for at least 8000 years (between 12,000 years BP and 4000 years BP), with very contradictory dates, which suggest even greater antiquity [22] [23] [24]. The first people settled in both caves and shelters under rock and open skies [20] [25] [26].

According to Miller [20] the region of the upper Madeira River shows evidence of older occupations dating from the beginning of the Holocene around 9000 years BP and includes the oldest black land sites throughout the Amazon region. Miller [22] study about a housing site (4780 \pm 90 years BP at $2640 \pm 60$ years old BP) showed an anthropogenic soil known as Amazonian Dark Earth $(\mathrm{ADE})$, together with lithic artifacts used in the processing of agricultural products, suggesting the existence of agricultural activities between the pre-ceramic groups.

The Santa Elina archaeological site, located about $650 \mathrm{~km}$ south of the Aripuanã city, Mato Grosso State, shows evidence of occupations by hunter societies and collectors around 12,000 to 4000 years BP [25]. In the Pedra City, at a distance of about $850 \mathrm{~km}$ south of the Aripuanã City, a set of archaeological sites presents evidences of occupations by hunters and collectors with about 4000 years BP, and a site known as Caverna do Cipó presents evidences of Occupations around 7000 years BP [26]. The Morro da Janela site located in the region of Rondonópolis, near the Pedra City, presented a 10,000-year BP dating [27].

Despite strong evidence of a Tupi origin in the region of the Alto Madeira River, the archaeology of the region is unknown. Miller [20] estimated a 2500 year BP for the earliest ceramic phase in the Alto Madeira River (Urucuri Phase). The authors suggest a new archaeological horizon for the Alto Madeira basin region based on the characteristics of the material culture and absolute dating. The Jamari Tradition consists of four phases: Urucuri, Jamari, Cupuí and Matapi, began around 2130 years BP, being the Una Tradition that occurs in Central Brazil.

Recently Zuse [28] has suggested the presence of Arawak cultural matrix peoples in the Alto Madeira region, between 3000 and 1500 years BP. In the subsequent period, that is, from 1500 years BP, occupations became denser due to the greater number of ceramic fragments observed in thicker archaeological 
layers of black earth, and with visible technological changes, whose demographic increase would have reached its Around 1000 BP, represented by Barrancoide ceramics. Also according to Zuse [28] the process of occupation of the region by sedentary, agricultural societies would have undergone profound transformations since the arrival of the holders of the Polícroma Tradition of the Amazon, called the Jatuarana Subtradition.

The Dardanelos 1 site is part of the Alto Madeira River, presenting high potential to generate information to test the models presented, since only a small portion of the archaeological site was affected by the construction of the Dardanelos Hydroelectric Power Plant.

\section{Data Acquisition and Processing}

Geophysical studies at the archaeological site of Dardanelos 1 started in July 2009. Several GPR profiles were acquired on two rectangular archaeological blocks classified as block-1 and block-2, which were selected based on their archaeological potential (Figure 1). The blocks have the following dimensions: block-1 has $24 \mathrm{~m}$ along the east-west direction (dir-x) and $10 \mathrm{~m}$ along the north-south direction (dir-y) and block-2 has $12 \mathrm{~m}$ along the East-west direction (dir-x) and $15 \mathrm{~m}$ along the north-south direction (dir-y).

108 GPR profiles were acquired with $200 \mathrm{MHz}$ shielded antennas with a SIR-3000 (GSSI) equipment (Figure 2). In block-1, 52 GPR profiles were acquired, with 31 profiles in the $\mathrm{x}$-direction (east-west) and 21 profiles in the $y$-direction (north-south). In block-2, 56 GPR profiles were acquired, with 31 profiles in the $\mathrm{x}$-direction (east-west) and 25 profiles in the $\mathrm{y}$-direction (northsouth). The reflection profiles with constant spacing were acquired in constant offset mode, with $0.5 \mathrm{~m}$ between each parallel profile and $0.02 \mathrm{~m}$ of trace interval. Each block allowed generating a volume of 3D data through the interpolation of $2 \mathrm{D}$ parallel profiles. The results were presented in the form of profiles and amplitude maps in depth-slices.

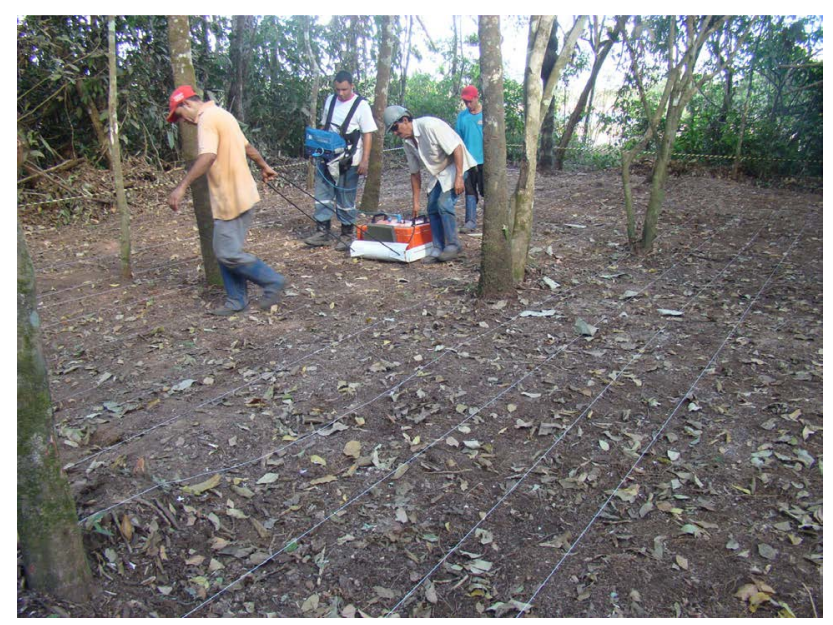

Figure 2. GPR equipment with $200 \mathrm{MHz}$ shielded antennas and grid used in data acquisition. 
Radan 7.0 software (GSSI) was used for GPR data processing. The main steps of the data processing were: zero time correction, bandpass temporal filtering, background removal, 3-traced moving average spatial filtering, time-variating linear gain, and time-to-depth conversion. To conclude, the conversion of the time profile to depth was done using the constant velocity of $0.07 \mathrm{~m} / \mathrm{ns}$. This velocity was calculated based on the fit of the hyperbola Dix equation [29] on the point targets identified in the reflection profiles.

Microwave tomography (MT) is an advanced data processing technique and has also been used in this research to improve GPR images in order to recover the geometry of the source of the anomalies that cause hyperbolic reflections. The theory of MT is described in the literature and consists of a problem of inversion of geophysical data [30] [31].

As the electric field irradiated by the transmitter antenna propagates through the geologic medium a backscattered electric field is registered by the receiver antenna when there are contrast sources below the surface. The summation of the irradiated electric field $\left(E_{i}\right)$ and the scattered electric field $\left(E_{s}\right)$ is the total electric field $\left(E_{t}\right)$, which is the radargram itself.

The solution for this inverse problem is an image that represents the contrast function of the surveyed area. The contrast function $(\chi)$ gives an image of the discretized space below the surface which allows a qualitative analysis of the contrast caused by inhomogeneities present in the soil, and is given by

$$
\chi=\left|\frac{\varepsilon-\varepsilon_{b}}{\varepsilon_{b}}\right|
$$

where $\varepsilon=\epsilon-i / \sigma \omega$ is the complex dielectric permittivity for each pixel in the image, $\epsilon$ is the real dielectric permittivity, $\sigma$ is the electric conductivity, $\omega$ is the angular frequency and $\varepsilon_{b}=\epsilon_{b}-i \sigma_{b} / \omega$ is the complex dielectric permittivity assumed for the homogeneous background.

The inverse problem in the microwave tomography is non-linear [30], thus it must be linearized. Although the complex dielectric permittivity is present in the equation, a quantitative analysis is not possible because of approximations done during the linearization of the inverse problem. Its linearization is done by means of the Born approximation [31], which assumes that the targets are small in terms of the wavelength and have low contrast compared to the background material. Some results of MT applied to GPR data can be found in literature, like in studies for archaeology and forensics [32] and underground features mapping [33] for instance. The tomographic images were obtained with the RadImage v1.0 program [34] and they are presented in the next section.

\section{Results Interpretation}

All $200 \mathrm{MHz}$ GPR profiles from each archaeological block were analyzed together and the results are presented in the form of amplitude maps in depth slices and 2D profiles. The GPR anomalies with the greatest archaeological potential are highlighted directly in the figures of depth slices and $2 \mathrm{D}$ profiles. 
These anomalies were selected for further archaeological excavations aiming the confirmation of the targets. The most expressive GPR results for each archaeological block studied are presented below.

\subsection{Block-1}

Figure 3 shows the amplitude map of the GPR signal in the form of depth slice to $0.62 \mathrm{~m}$ for block-1. Note a well-defined rectangular-shaped anomaly (A1) with high amplitude at the center of the figure (position $\mathrm{x}=11.3 \mathrm{~m}-13.5 \mathrm{~m}, \mathrm{y}=$ $5.2 \mathrm{~m}-7.0 \mathrm{~m}$ ). According to field observations, this rectangular-shaped anomaly is related to a previous excavation done in the studied area that had to be halted due to time constrains, and was resumed in the following year. According to Conyers [4] GPR profiles with high amplitude reflectors are more likely to be related to archaeological targets, but may also be associated with buried natural targets, for example, silicified tree roots [16], bedrock [17], among others. Note also the presence of a reflector with high amplitude of elongated and continuous format (TR) (position $\mathrm{x}=21 \mathrm{~m}-22 \mathrm{~m}, \mathrm{y}=0 \mathrm{~m}-5 \mathrm{~m}$ ). This elongated anomaly corresponds to the tree root according to local excavation.

Figure 4(a) shows a GPR profile in the y-direction corresponding to the position $\mathrm{x}=12 \mathrm{~m}$ (indicated by an arrow in Figure 3 ). The reflection pattern is quite complex, showing two strong sub-horizontal reflectors at approximately $1 \mathrm{~m}$ and $2 \mathrm{~m}$ depths. Note also a clear anomaly characterized by a high amplitude hyperbolic reflector (A1) with vertex at the $6 \mathrm{~m}$ position, corresponding to the anomaly observed in Figure 3. Figure 4(b) shows the tomographic image corresponding to Figure $4(\mathrm{a})$. Note in the position of $6 \mathrm{~m}$ the anomaly A1 with approximately circular geometry.

The analysis of the anomaly A1 (Figure 3 and Figure 4) showed that it is the same target and is therefore suitable for archaeological excavations. Figure 5 shows the result of the archaeological excavation on the A1 anomaly. The excavation revealed an indigenous urn of circular shape in the middle of a soil rich in organic matter characterized by black soil.

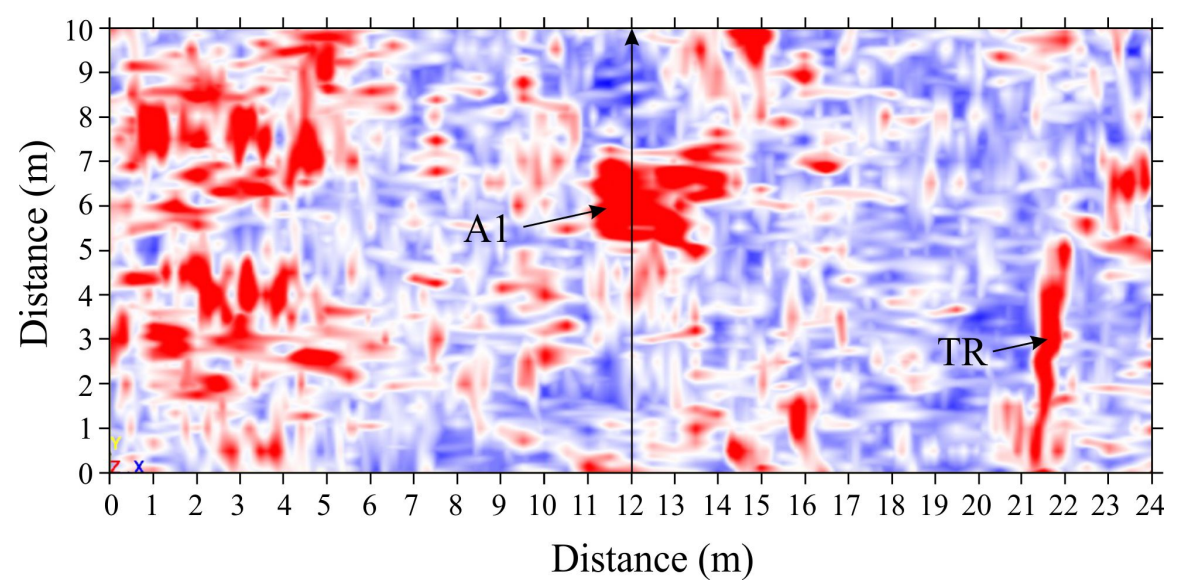

Figure 3. GPR signal amplitude map in depth slice form for $0.62 \mathrm{~m}$ for block-1. 


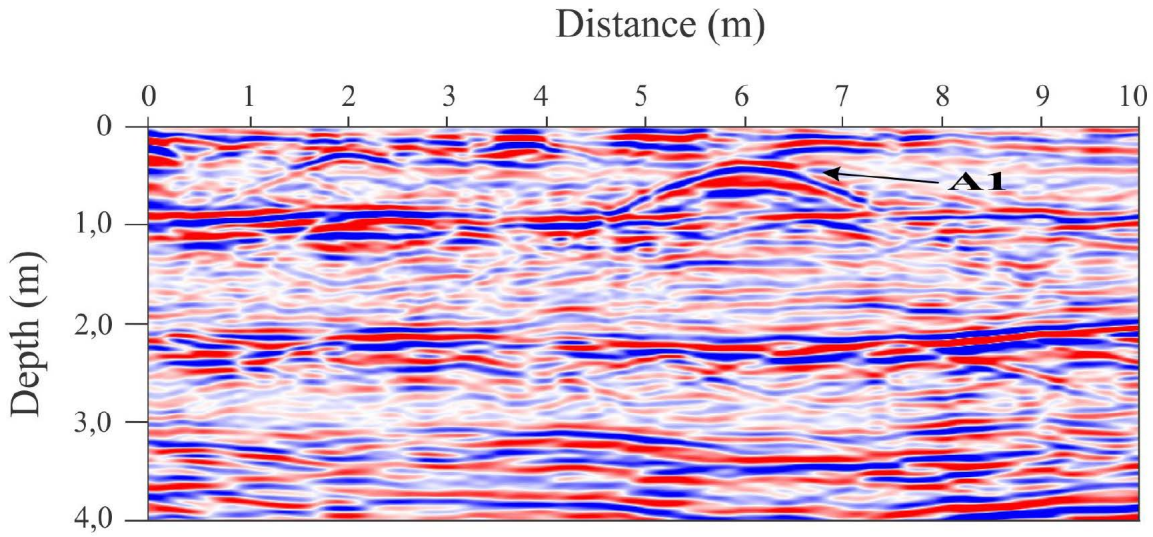

(a)

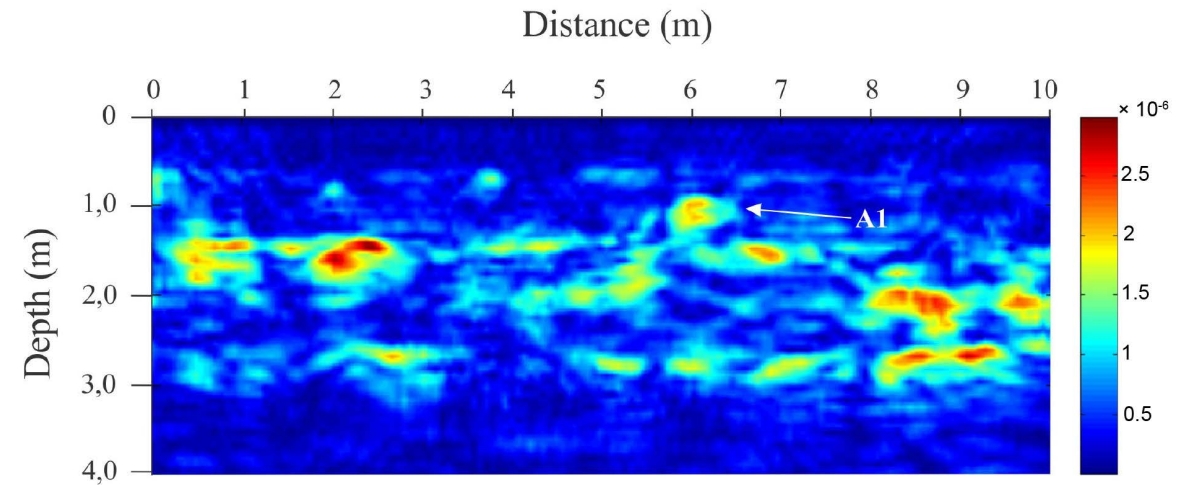

(b)

Figure 4. (a) GPR profile for block-1 in the y-direction corresponding to the position $\mathrm{x}=$ $12 \mathrm{~m}$; (b) GPR tomographic image of Figure 4(a).

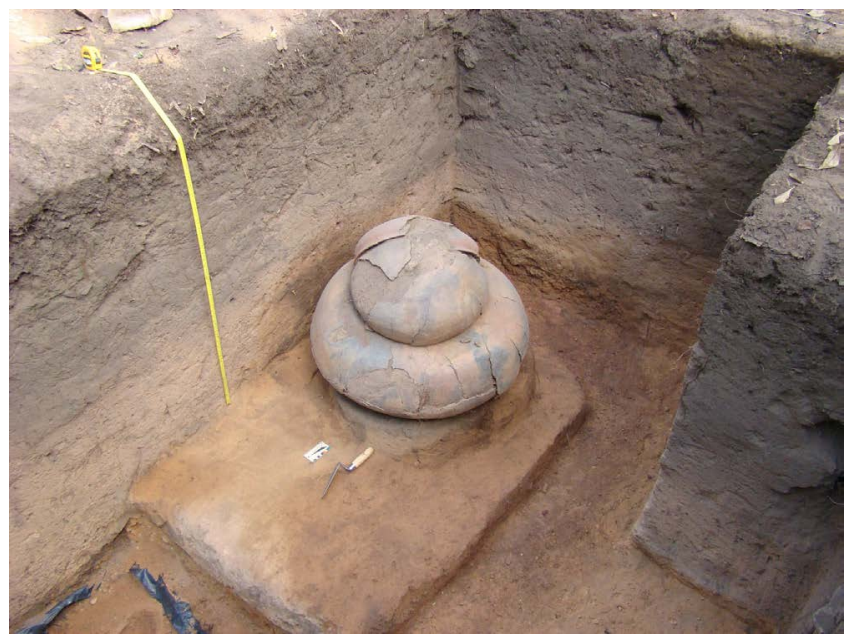

Figure 5. Photography of the archaeological excavation carried out on the anomaly A1 of block-1, showing an indigenous urn.

\subsection{Block-2}

Figure 6 shows a GPR depth slice for $0.60 \mathrm{~m}$ for block-2. The presence of a discontinuous point anomaly (A2) with small dimensions (position $\mathrm{x}=2.9 \mathrm{~m}-3.5 \mathrm{~m}$, 


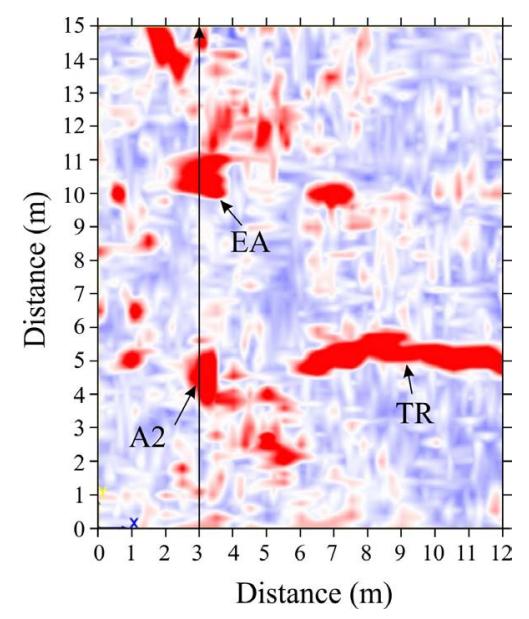

Figure 6. GPR signal amplitude map in depth slice form for $0.60 \mathrm{~m}$ for block-2.

$y=3.7 \mathrm{~m}-5.3 \mathrm{~m}$ ) is also observed. Notice another square-shaped discontinuous point anomaly (EA) (position $\mathrm{x}=2.4-3.6 \mathrm{~m}, \mathrm{y}=10-11.2 \mathrm{~m}$ ). It is worth noting that this is a punctual and discontinuous anomaly, and may be related to a target with archaeological potential due to the geometry and its dimensions. Note in this figure the presence of an elongated and continuous high - amplitude reflector (TR) (position $\mathrm{x}=6 \mathrm{~m}-12 \mathrm{~m}, \mathrm{y}=4.7 \mathrm{~m}-5.5 \mathrm{~m}$ ).

Figure 7(a) shows a GPR profile in the y-direction corresponding to the position $\mathrm{x}=3.0 \mathrm{~m}$ (indicated by an arrow in Figure 6), crossing over the anomaly A2. Again the reflection pattern is complex, showing two sub-horizontal reflectors, as well as a sharp hyperbolic anomaly of high amplitude (A2) with vertex at the position of $4.9 \mathrm{~m}$, corresponding to the anomaly A2 observed in Figure 6 . Note also a vertical anomaly between the position $y=10-11.2 \mathrm{~m}$, coinciding with the anomaly (EA) observed in Figure 6. Figure 7(b) shows the tomographic image corresponding to Figure 7(a). Observe in the position of $4.9 \mathrm{~m}$ and around $0.5 \mathrm{~m}$ deep (Figure $7(\mathrm{~b})$ ) a clear anomaly with circular geometry corresponding to hyperbola A2 (Figure 7(a)).

Similar to the excavations made in block-1, the GPR results guided the archaeological excavations on the A2 anomaly observed in Figure 6 and Figure 7. Figure 8 shows the result of the archaeological excavation on the A2 anomaly. This excavation also revealed an indigenous urn of circular shape in the middle of a soil rich in ceramic materials mixed with organic matter consisting of black earth up to about $1 \mathrm{~m}$ deep.

The anomalies in continuous elongated (TR) (Figure 3 and Figure 6) were not characterized as a target of archaeological interest, because they are very shallow. These anomalies were related to the presence of tree roots (TR) that are common in the study area.

The analysis of the GPR 2D profiles (Figure 4(a) and Figure 7(a)), besides allowing the detection of hyperbolic anomalies, also permit to detection of two high-amplitude sub-horizontal reflectors that occur around $1 \mathrm{~m}$ and between 


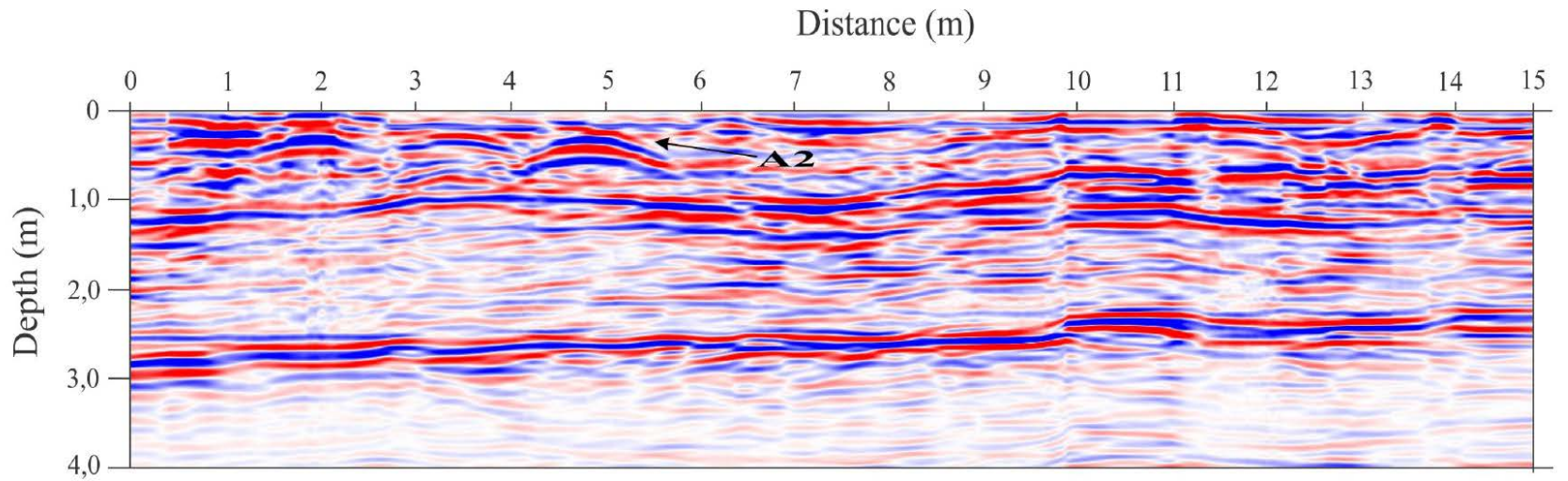

(a)

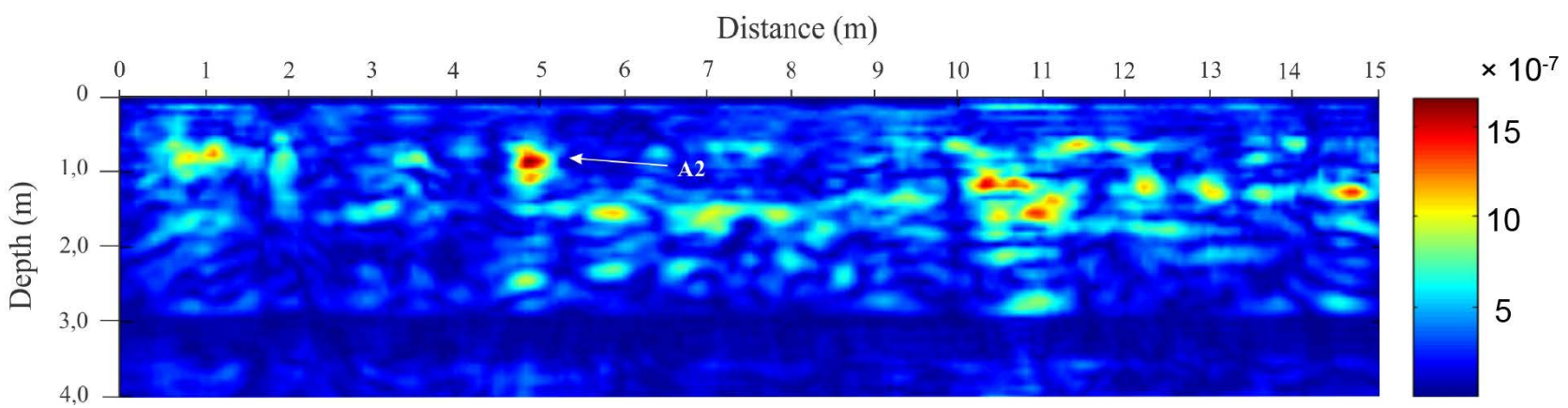

(b)

Figure 7. (a) GPR profile for block-2 in the y-direction corresponding to the position $x=3 \mathrm{~m}$; (b) GPR tomographic image of Figure 7(a).

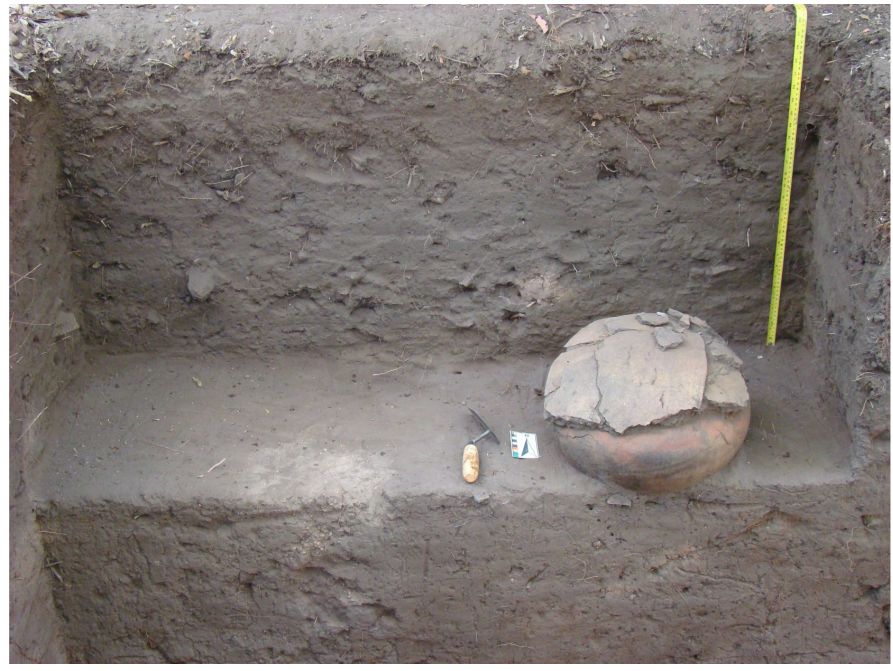

Figure 8. Photography of the archaeological excavation carried out on the anomaly A2 of block-2, showing an indigenous urn.

2 - $3 \mathrm{~m}$ depth. Excavations of hyperbolic anomalies have revealed targets of archaeological interest. The first sub-horizontal reflector showed good agreement with the base of the black earth layer rich in organic matter and ceramic shards. Additionally, the second sub-horizontal reflector may be related to a lithological 
change or to the presence of water table. These interpretations are only speculative and are beyond the scope of this work.

\section{Conclusions}

The microwave tomography GPR results with $200 \mathrm{MHz}$ antennas permit to detect geophysical anomalies in depth slices and reflection profiles. The anomalies were characterized by hyperbolic reflectors and sub-horizontal structures. Hyperbolic anomalies indicated areas with great potential for finding archaeological targets. Microwave tomography improved the spatial positioning and allowed estimating the geometry of GPR anomalies.

Excavations in blocks 1 and 2 revealed positive results with the location of urns related to hyperbolic anomalies. The first sub-horizontal structure at $1 \mathrm{~m}$ depth corresponds to the base of the black earth layer rich in organic matter and ceramic shards. Shallow continuous anomalies were related to the tree roots that are common in the Amazon region.

The results showed the efficiency of the GPR method for detecting archaeological targets at the site of Dardanelos 1 . The studies guided the archaeological excavations, reduced exploration costs, and contributed to the preservation of national historical patrimony.

\section{Acknowledgements}

We thank Energética Águas da Pedra e Scientia Consultoria for all the financial, logistical e fieldwork support. JLP thanks to CNPq-National Council for Scientific and Technological Development for the Research PQ-1D (Grant: 301692/2013-0). RK thanks to CNPq PQ-2D (Grant: 300892/2005-5). VRNS thanks to Fapesp for his postdoctoral fellowship (Grant: 2014/18209-6). ERA thanks to Fapesp for his postdoctoral fellowship (Grant: 2016/25929-0). IF thanks CAPES-Coordination of Improvement of Higher Education for the Master's degree. IAG/USP is also grateful for the support and infrastructure. We thank Ernande Costa Santos and the people who assisted in the acquisition of geophysical data.

\section{References}

[1] Daniels, D.J. (2007) Ground Penetrating Radar. IET Radar, Sonar, Navigation and Avionics Series 15. 2nd Edition. 734 p.

[2] Jol, H.M. (2009) Ground Penetrating Radar: Theory and Applications. Elsevier, USA.

[3] Conyers, L.B. and Goodman, D. (1997) Ground Penetrating Radar-An Introduction for Archaelogists. Altamira Press, London.

[4] Conyers, L.B. (2004) Ground Penetrating Radar for Archaelogy. Altamira Press, USA.

[5] Pipan, M., Baradello, L., Forte, E., Prizzon, A. and Finetti, I. (1999) 2-D and 3-D Processing and Interpretation of Multi-Fold Ground Penetrating Radar Data: A Case History from an Archaeological Site. Journal of Applied Geophysics, 41, 271-292. https://doi.org/10.1016/S0926-9851(98)00047-0

[6] Chamberlain, A.T., Sellers, W., Proctor, C. and Coard, R. (2000) Cave Detection in 
Limestone Using Ground Penetrating Radar. Journal of Archaeological Science, 27, 957-964. https://doi.org/10.1006/jasc.1999.0525

[7] Weinstein-Evron, M., Beck, A. and Ezersky, M. (2003) Geophysical Investigations in the Service of Mount Carmel (Israel). Journal of Archaeological Science, 30, 1331-1341. https://doi.org/10.1016/S0305-4403(03)00023-2

[8] Persson, K. and Olofsson, B. (2004) Inside a Mound: Applied Geophysics in Archaeological Prospecting at the Kings' Mounds, Gamla Uppsala, Sweden. Journal of Archaelogical Science, 31, 551-562. https://doi.org/10.1016/j.jas.2003.10.003

[9] Watters, M.S. (2004) GPR: A Tool for Archaeological Management. Tenth International Conference on Ground Penetrating Radar, Delft, 21-24 June 2004.

[10] Leucci, G. and Negri, S. (2005) Use of Ground Penetrating Radar to Map Subsurface Archaeological Features in an Urban Area. Journal of Archaeological Science, 33, 502-512. https://doi.org/10.1016/j.jas.2005.09.006

[11] Sauck, W.A., Smart, L.A., Nassaney, M.S. and Porsani, J.L. (2006) Archaeological Geophysics in an Urban Environment: Peeling Back the Layers at Ft. Miami, Michigan. Proceedings of 19 th Symposium on the Application of Geophysics to Engineering and Environmental Problems, Seattle, 2-6 April 2006, 499-551. https://doi.org/10.4133/1.2923685

[12] Roosevelt, A.C. (1991) Moundbuilders of the Amazon: Geophysical Archaeology on Marajó Island, Brazil. Academic Press.

[13] Bevan, B.W. and Roosevelt, A.C. (2003) Geophysical Exploration of Guajará, a Prehistoric Earth Mound in Brazil. Geoarchaeology, 18, 287-331.

https://doi.org/10.1002/gea.10064

[14] Cezar, G.S., Rocha, P.L.F., Buarque, A. and Costa, A. (2001) Two Brazilian Archaeological Sites Investigated by GPR: Serrano and Morro Grande. Journal of Applied Geophysics, 47, 227-240.

[15] Schimmel, P.B., Porsani, J.L., Figuti, L. and de Blasis, P. (2002) Aplicação de métodos geofísicos em arqueologia: Primeiros resultados obtidos no sambaqui fluvial Capelinha, Cajati-SP, Brasil. Revista do Museu de Arqueologia e Etnologia da USP, 12, 43-54.

[16] Rodrigues, S.I., Porsani, J.L., Santos, V.R.N., DeBlasis, P.A.D. and Giannini, P.C.F. (2009) GPR and Inductive Electromagnetic Surveys Applied in Three Coastal Sambaqui (Shell Mounds) Archaeological Sites in Santa Catarina State, South Brazil. Journal of Archaeological Science, 36, 2081-2088.

[17] Porsani, J.L., Jangelme, G.M. and Kipnis, R. (2010) GPR Survey at Lapa Do Santo Archaeological Site, Lagoa Santa Karstic Region, Minas Gerais State, Brazil. Journal of Archaeological Science, 37, 1141-1148.

[18] Allen, S.J., Porsani, J.L. and Poluha, B. (2017) Geofísica Arqueológica no Ambiente da Arqueologia Urbana: Proposta Metodológica para Projetos Públicos. Revista de Arqueologia da $S A B, 30,235-254$. https://doi.org/10.24885/sab.v30i1.510

[19] Kipnis, R. (2016) Estudos Etnohistóricos, Arqueológicos e Etnoarqueológicos das Comunidades Indígenas na Região de Aripuanã/MT Relatório Final. Scientia Consultoria Científica, São Paulo.

[20] Miller, E.T. (1992) Arqueologia nos empreendimentos hidrelétricos da Eletronorte; resultados preliminares. Brasilia, DF, Eletronorte.

[21] Neves, E.G. (2006) Arqueologia da Amazônia. Jorge Zahar Editor, Rio de Janeiro.

[22] Miller, E.T. (1987) Pesquisas arqueológicas paleoindígenas no Brasil Ociendetal. Estudios Atacameños, 8, 9-15. 
[23] Vilhena-Vialou, A. and Vialou, D. (1994) Les premiers peuplement préhistorique du Mato Grosso. Bulletin de la Société Préhistorique Française, 91, 257-263. https://doi.org/10.3406/bspf.1994.9734

[24] Vilhena-Vialou, A., Aubry, T., Benabdelhadi, M., Cartelle, C., Figuti, L., Fontugne, M., Solari, M.E. and Vialou, D. (1995) Découverte de Mylodontinae dans un habitat préhistorique daté du Mato Grosso (Brésil): L'abri rupestre Santa Elina. Compte Rendus de P Académie des Sciences, 230, 655-661.

[25] Vialou, A.V. (2005) Pré-história do Mato Grosso. Vol. 1, Santa Elina, EDUSP, São Paulo.

[26] Vialou, A.V. (2006) Pré-história do Mato Grosso. Vol. 2, Cidade de Pedra, EDUSP, São Paulo.

[27] Wüst, I. and Vaz, L.J.M. (1998) Grafismos de ação no alto São Francisco, sudeste do Mato Grosso. Revista do Museu Antropológico, 2, 47-88.

[28] Zuse, S. (2014) Variabilidade cerâmica e diversidade cultural no Alto rio Madeira, Rondônia. D.Sc. Thesis, Museu de Arqueologia e Etnologia da Universidade de São Paulo.

[29] Dix, C.H. (1955) Seismic Velocities from Surface Measurements. Geophysics, 20, 68-86. https://doi.org/10.1190/1.1438126

[30] Leone, G. and Soldovieri, F. (2003) Analysis of the Distorted Born Approximation for Subsurface Reconstruction: Truncation and Uncertainties Effects. IEEE Transactions on Geoscience and Remote Sensing, 41, 66-74.

https://doi.org/10.1109/TGRS.2002.806999

[31] Soldovieri, F., Hugenschmidt, J., Persico, R. and Leone, G. (2007) A Linear Inverse Scattering Algorithm for Realistic GPR Applications. Near Surface Geophysics, 5, 29-41. https://doi.org/10.3997/1873-0604.2006016

[32] Almeida, E.R., Porsani, J.L., Catapano, I., Gennarelli, G. and Soldovieri, F. (2016) Microwave Tomography-Enhanced GPR in Forensic Surveys: The Case Study of a Tropical Environment. IEEE Journal of Selected Topics in Applied Earth Observations and Remote Sensing, 9, 115-124. https://doi.org/10.1109/JSTARS.2015.2466556

[33] Porsani, J.L., Almeida, E.R., Poluha, B. and Santos, V.R.N. (2017) GPR Tomographic Imaging of Concrete Tubes and Steel/Plastic Tanks Buried in IAG/USP Geophysical Test Site, Brazil. International Journal of Geosciences, 8, 647-658. https://doi.org/10.4236/ijg.2017.85035

[34] Almeida, E.R. and Porsani, J.L. (2017) RadImage V1.0. Programa para processamento de dados GPR. Software registrado pelo Instituto Nacional da Propriedade Industrial do Brasil. Número do Registro: BR512016001778-3.

[35] Google (2015) Google Earth. Version 7.1.7.2606. Instituto de Astronomia, Geofísica e Ciências Atmosféricas USP. https://www.google.com/earth/ 